\title{
The Influence of Financial Disclosure, Ownership Structure on Corporate Value with Dividend Policy as Moderating Variable
}

\author{
Nurna Aziza'1, Vika Fitranita ${ }^{2}$, Nofrilia Monica ${ }^{3}$ \\ The University of Bengkulu ${ }^{1,2,3}$ \\ \{izabk1.76@gmail.com¹, Vika.fitranita@unib.ac.id ${ }^{2}$,Nofrilia.monica30@gmail.com³ $\}$
}

\begin{abstract}
This study aimed to examine the effect of financial disclosure, ownership structure on corporate value with dividend policy as moderating effect. The sample in this study are the companies index LQ45 that are included in the Indonesia Stock Exchange in 2012 - 2019. Sample selection is taken by purposive sampling method. The number of observations of this study are 120 observations. Hypotheses are examined using partial least square (PLS). The result showed that the financial disclosure has a no influence on corporate value, ownership structure has a no influence on corporate value. In addition dividend policy has a no moderate financial disclosure on corporate value, dividend policy has a no moderate ownership structure on corporate value.
\end{abstract}

Keywords: financial disclosure; dividend policy; corporate value

\section{Introduction}

The company was founded with the aim of increasing the prosperity of its shareholders. The main economic goal that managers in the organization want to achieve is to maximize shareholder value. The company value describes the welfare of the shareholders as well as the prospects for the company in the future. The increase in company value will be followed by an increase in the prosperity of the shareholders (Surya and Basuki, 2012: 179). The objective of maximizing shareholder value can be achieved by maximizing resource allocation. Shareholder value can be seen from earnings, cash flow or financial statement ratios (Worthington and Tracey, 2004; in Shahwan, 2019). Therefore, company stakeholders can use this information to see the company's future capabilities.

The maximization of firm value is influenced by the manager (agent) who is the party authorized by the shareholders (principal) to carry out the company's operations. Assuming that individuals act in maximizing their own interests, the information asymmetry that can occur will encourage agents to hide some information from the principal. Asymmetric information will make shareholders wrong in making decisions. To ensure that shareholders are not exploited by managers, financial disclosures are needed to provide reliable information.

Financial disclosure in financial statements is a means of communication between managers and shareholders containing financial and non-financial information about the company. Lien (2003) states that financial reporting can affect investors because investors 
need information about current and future cash flows so that they can assess companies to make investment decisions.

In addition, firm value is influenced by ownership structure. Ownership structure is important in the company because it monitors the course of the company in achieving its goals, namely maximizing company value. Majority shareholders will have more flexibility in supervising the company than minority shareholders. Jansen and Warner (1988) in Lukviarman (2016) argue that ownership structure can determine the characteristics or levels of agency conflict, which causes a mapping of the division between power and supervision in a company. Yuniati et al. (2016) stated that share ownership structure is a mechanism to reduce conflict between management and shareholders.

Jensen and Meckling (1976) state that dividends are one of the policies undertaken to address corporate agency problems. Dividend policy is a decision owned by the management of the company to distribute profits or profits as dividends or to be retained in the form of retained earnings (Agus, 2011). The dividend policy determined by the manager is based on the financial disclosures in the annual financial statement information. This financial information includes, among others, dividends per share, earnings per share, total assets and total liabilities (Mmbone et al., 2015). Thus, financial disclosure provides hint for managers to formulate a sound and effective dividend policy that will attract potential investors and encourage existing investors to reinvest.

Jensen (1986) states that managers and shareholders always have different interests which is known as agency conflict. Jensen further stated that one of the problems between managers and shareholders is that shareholders prefer to distribute dividends rather than be reinvested while managers are the opposite. So that dividend policy will affect the relationship between the company's ownership structure. This study refers to Shahwan's (2019) research with firm value as the dependent variable. Financial disclosure and addition of new variables, namely ownership structure as independent variables. Dividend policy in this study is a moderating variable between financial disclosure and ownership structure on firm value

\section{Theoretical Framework and Hypotheses}

\subsection{Agency Theory}

This theory was first developed by Michael C. Jensen and William H. Meckling in 1976. Agency relationship is a relationship between two parties, where the first party acts as the principal / authority giver and the second is called an agent who acts as an intermediary to represent the principals. in conducting transactions with third parties. Principals referred to in the company are shareholders who provide a number of funds for the continuity of the company's operations. The agent is the party responsible for running the company for the advancement and prosperity of the shareholders.

\subsection{The value of the company}

The value of the company is a reflection of the conditions that have been achieved by a company as a reflection of the public's trust in the company after going through a process of activities for several years, namely since the company was founded until now (Noerirawan, 2012). investors recognize the company's potential, both current and future, through its market assessment. 


\subsection{Financial Disclosure}

Financial disclosure is the delivery of information in financial reports which includes financial statements, notes on reports and disclosures related to reports (Evans, 2010). The information in the financial statements is not fully presented, so it is necessary to have notes on the financial statements that will help users of financial statements to understand the financial condition of a company in a certain period. Financial disclosures are used to improve historical analysis and encourage potential investors to improve their ability to plan and evaluate income levels in the long term through good and precise income estimates (Klapper and Love, 2002). Financial disclosure will help investors in predicting company performance and will increase company value (Mmbone et al., 2015).

$\mathrm{H} 1$ : Financial disclosure has a positive effect on firm value

\subsection{Ownership structure}

Ownership structure is a comparison between the number of shares owned by insiders (insider) and the number of shares owned by investors (Jahera and Aurburn, 1996). In other words, ownership structure is the proportion of institutional ownership and management ownership in company stock ownership. The ownership structure will be able to coordinate the company to achieve the company's goals, namely maximizing the prosperity of its shareholders. Variations in the leadership structure will be able to form supervision within the company so that the company's management performance is in line with the interests of shareholders. Supervision within the company will create control over management actions so as to increase company value (Fahdiansyah et al., 2017).

$\mathrm{H} 2$ : Ownership structure has a positive effect on firm value

\subsection{Financial Disclosure and Dividend Policy}

The dividend policy set by the manager is based on financial disclosure in the annual financial report information. This financial information includes dividends per share, earnings per share, total assets and total liabilities, among others (Mmbone et al., 2015). Investors see dividend policy as a source of information that communicates the company's future financial viability (Al-Kuwari, 2009). A stable dividend policy within the company will create a good reputation, reflecting the prosperity of the shareholders. Lin et al. (2016) argue that companies with lower disclosures must pay higher dividend rates to create a reputation for good shareholder care. In other words, the dividend policy in the company affects the extent of information conveyed by management in the financial disclosure in the financial statements which will be the basis for investors to make investment decisions.

H3: Dividend policy moderates the relationship between financial disclosure and firm value.

\subsection{Ownership Structure and Dividend Policy}

Shareholders share the company's cash flow in the form of dividends to reduce agency costs from the company's free cash (Eckbo and Verma, 1994). In the agency perspective, companies are required to provide high dividend rates to shareholders and management who make capital through external scales, thus demanding that the company be controlled by the company (Short et al. 2002). 
The dividend policy adopted by the company will affect the relationship between share ownership and firm value. This decision will affect the existing shareholders in the company (ownership structure). Dividends that will be distributed in a certain period to shareholders will be directly felt by investors.

H4 : Dividend policy moderates the relationship between ownership of firm value.

\section{Methods}

\subsection{Sample}

The population in this study were all LQ45 companies listed on the Indonesia Stock Exchange (BEI) in 2020 with an observation period of 2012-2019. The sampling method in this study used purposive sampling method, namely the sampling method based on certain criteria. Table I shows that the samples that met the sampling criteria in this study were 15 companies with 120 observations.

Table 1. Companies sample 0bsertvation

\begin{tabular}{lc}
\hline \multicolumn{1}{c}{ Perusahaan Sampel Penelitian } & Jumlah Perusahaan \\
\hline Companies listed on LQ45 in 2020 & 45 \\
LQ45 companies that did not publish financial statements for the & \\
financial year ended December 31 between the 2012-2019 & (1) \\
period) & \\
Manufacturing companies that do not report the accounts needed \\
to perform variable calculations in the study
\end{tabular}

\subsection{Data Analysis}

This research uses SmartPLS analysis. The independent variable in this study is financial disclosure and ownership structure, while the dependent variable is firm value and the moderating variable is dividend policy. The company value indicator is measured using ROA and ROE. Financial disclosure variable indicators are measured using the liquidity ratio, asset turnover ratio and debt to equity ratio. The indicator of ownership structure variables is measured using managerial ownership and institutional ownership. And dividend policy indicators are measured using the dividend payout ratio and earnings per share.

Table 2. Analysis Data

\begin{tabular}{|c|c|c|c|}
\hline Variables & Descriptions & Indikator & Source \\
\hline $\begin{array}{l}\text { the value of } \\
\text { the company }\end{array}$ & $\begin{array}{l}\text { Dependent } \\
\text { Variable }\end{array}$ & ROA dan ROE & Shahwan, (2019) \\
\hline $\begin{array}{l}\text { Financial } \\
\text { disclosure }\end{array}$ & $\begin{array}{l}\text { Independent } \\
\text { Variable }\end{array}$ & $\begin{array}{l}\text { Liquidity ratio (LR), Aset Turnover } \\
\text { Ratio (ATR) dan Debt Equity Ratio } \\
\text { (DER) }\end{array}$ & Mmbone et al, (2015) \\
\hline $\begin{array}{l}\text { Financial } \\
\text { disclosure }\end{array}$ & $\begin{array}{l}\text { Independent } \\
\text { Variable }\end{array}$ & $\begin{array}{l}\text { Managerial Ownership and } \\
\text { Institutional Ownership 1 }\end{array}$ & $\begin{array}{l}\text { Apriada dan Sadha, } \\
\text { (2016) }\end{array}$ \\
\hline $\begin{array}{l}\text { Dividend } \\
\text { Policy }\end{array}$ & $\begin{array}{l}\text { Moderating } \\
\text { Variable }\end{array}$ & $\begin{array}{l}\text { Dividend payout ratio (DPR) dan } \\
\text { Earning per Share (EPS) }\end{array}$ & $\begin{array}{l}\text { Mbuva et al, (2017) } \\
\text { dan Kajola et al, } \\
(2015)\end{array}$ \\
\hline
\end{tabular}




\section{Results and Discussion}

\subsection{Descriptive Statistics}

Descriptive statistics used in this study are the maximum value, minimum value, average value (mean), and standard deviation of the firm value variables, financial disclosure, ownership structure, and dividend policy. Descriptive statistics in this study are presented in Table 3.

Table 3. Descriptive Statistics

\begin{tabular}{cccccc}
\hline \multicolumn{5}{c}{ Descriptive Statistics } \\
\hline & $\mathbf{N}$ & Minimum & Maximum & Mean & Std. Deviation \\
\hline ROA & 120 & 0,0005783 & 0,4666014 & 0,124297723 & 0,0999785044 \\
ROE & 120 & 0,0012896 & 1,3996649 & 0,244543768 & 0,2922019207 \\
LR & 120 & 0,6056319 & 9,7169205 & 2,186951220 & 1,4234329865 \\
ATR & 120 & 0,3870192 & 3,3797605 & 1,134248893 & 0,6461151974 \\
DER & 120 & 0,1864457 & 2,9094870 & 0,904047548 & 0,5677771710 \\
KM & 120 & 0,0000003 & 0,1596612 & 0,012106551 & 0,0355008019 \\
KI & 120 & 0,0464540 & 0,9577944 & 0,595486122 & 0,1919272210 \\
DPR & 120 & 0,0000436 & 1,8149809 & 0,542451641 & 0,3480176929 \\
EPS & 120 & 0,0003356 & 5654,9929110 & 539,221525520 & 977,5984229189 \\
\hline
\end{tabular}

Table 3 shows that on average, LQ45 companies are companies that have a profitable level and are able to manage effectively and efficiently assets and capital in generating profits. In the financial disclosure variable, on average, the sample companies have a good financial condition so that the published information will be broad and credible. The dividend policy variable shows that the sample companies have a stable dividend payout rate, thus indicating that the company has a high level of concern for the welfare of shareholders.

\subsection{Results of the PLS Algorithm}

Table 4. PLS algorithm

\begin{tabular}{cccc}
\hline Laten Variable & Indicator & Outer Loading & Composite Reliability \\
\hline \multirow{2}{*}{ the value of the company } & ROA & 0,899 & \multirow{2}{*}{0,934} \\
& ROE & 0,972 & \\
Financial disclosure & LR & $-3,095$ & 0,450 \\
& ATR & 0,832 & \\
\multirow{2}{*}{ Ownership structure } & DER & 0,719 & 0,049 \\
& KI & 0,831 & \\
Dividend policy & KM & $-0,612$ & 0,691 \\
\hline
\end{tabular}

The results of processing using SmartPLS can be seen in Table 4.3 showing that most of the indicators show the value of outer loading $>7$, although some indicators such as KM and LR are still below 0.7. This indicator can still be maintained because it is a reflective construct that cannot stand alone. Based on the cross loading value in Table 4.4, it can be seen that most of the indicators have the highest cross loading value on the construct or the latent variable it 
represents when compared to the cross loading value of other latent variables. This shows that each variable has a good discriminant value validity as indicated by the cross loading value of the measurement indicator. However, the LR and KM indicators have the lowest cross loading values -0.395 and -0.612 , respectively.

\subsection{Path Coefficients Analysis Figure}

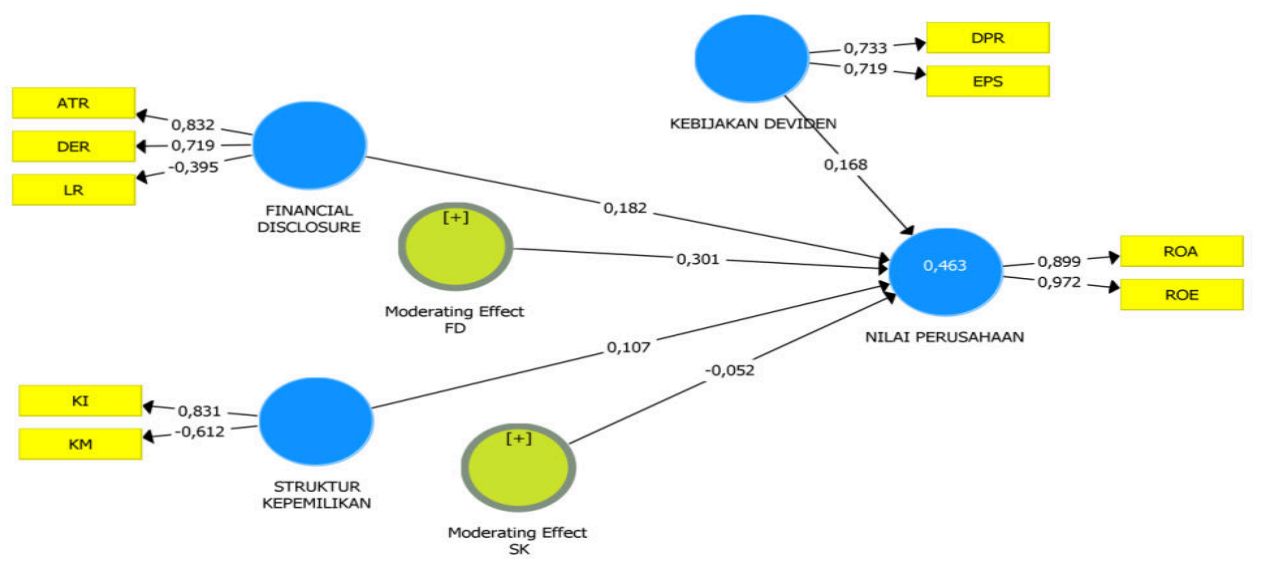

Fig. 1. Diagrammatic Results of PLS

Thus, Figure 1 above presents the diagrammatic results of the PLS regression-algorithm aimed at showing the extent to which the independent latent variable contributes to the prediction of the dependent variable. Therefore, exogenous variables have contributed 0.463 equivalent to $46.30 \%$ in the prediction of endogenous latent variables.

\subsection{Hypothesis Testing Results}

Table 5. Output Effect Bootstrapping

\begin{tabular}{lccccc}
\hline \multicolumn{1}{c}{ Variable } & $\begin{array}{c}\text { Original } \\
\text { Sample (O) }\end{array}$ & $\begin{array}{c}\text { Sample } \\
\text { Mean (M) }\end{array}$ & $\begin{array}{c}\text { Standard Deviation } \\
\text { (STDEV) }\end{array}$ & $\begin{array}{c}\text { T Statistics } \\
(\mid \mathbf{O} / \text { STDEV } \mid)\end{array}$ & P Values \\
\hline FD -> NP & 0,182 & 0,186 & 0,121 & 1,498 & 0,135 \\
SK -> NP & 0,107 & 0,060 & 0,116 & 0,920 & 0,358 \\
ME FD -> KD & 0,301 & 0,325 & 0,084 & 3,563 & 0,000 \\
ME SK -> KD & $-0,052$ & $-0,011$ & 0,123 & 0,421 & 0,674 \\
\hline
\end{tabular}

source: Research Results, (2020)

The results of testing the first hypothesis indicate that there is no effect of financial disclosure on firm value with a t-statistic value of 1.498 (t-statistical value $<1.64)$ and a $\mathrm{p}$ value of 0.135 ( $\mathrm{p}$ value $>0.05$ ). The original sample value shows a positive value of 0.182 which indicates that the financial disclosure construct and firm value have a positive effect. Thus it can be concluded that financial disclosure is not significant and has a positive effect on firm value. This shows that the first hypothesis in this study is rejected.

The results of hypothesis testing show that there is no influence between ownership on firm value with a t-statistic value of 0.920 (statistical value $<1.64$ ) and a p-value of 0.019 (p value $>0.05$ ). The original sample value shows a positive value of 0.107 which indicates that the ownership structure construct and firm value have a positive effect. Thus it can be ignored 
that the ownership structure is not significant and has a positive effect on firm value. This shows that the second hypothesis in this study is rejected.

Hypothesis 3 testing is to see the role of dividend policy as a moderating variable between financial disclosure and firm value. The moderation test is significant with a t-statistic value of $3,563$ (t-statistical value $>1.64)$ and a p-value of 0,000 ( $p$-value $<0.05)$. However, the test between the independent variable (financial disclosure) and the dependent variable, namely (firm value), is not significant. This test is a full moderation tester, where the moderating variable has an effect while the independent variable on the dependent variable has no effect.

The results of testing hypothesis 4 indicate that dividend policy has no effect on share ownership on firm value. This can be seen from the t-statistic value of 0.421 (t-statistic value $<1.64$ ) and $p$ value of 0.674 ( $p$ value $>0.05$ ). Thus, it can be argued that dividend policy does not moderate the relationship between ownership and firm value. This shows that the fourth hypothesis in this study is rejected.

\section{Conclusion}

This study aims to obtain empirical evidence regarding the effect of financial disclosure, ownership structure on firm value moderated by dividend policy. This study uses a sample of companies LQ45 in 2020 with an observation period of 2012 - 2019. The results show that financial disclosure has no effect on firm value, ownership structure does not affect firm value, dividend policy cannot moderate the relationship between financial disclosure and firm value. dividends cannot moderate the relationship between ownership structure and firm value.

\subsection{Implikasi}

The theory tested in this study is agency theory. The results of this study cannot confirm agency problems, namely information asymmetry and alignment of interests between managerial and institutional parties. In the results of this study, the variables financial disclosure and ownership structure cannot explain agency problems. Thus financial disclosure does not reduce information asymmetry and ownership structure cannot align interests between management and the company's institutional parties.

Dividend policy is more appropriate as an independent variable and financial disclosure is more appropriate as a moderating variable. A company's dividend policy will be good if the source of the determination comes from clear financial disclosure. Dividend policy will be good if it comes from the company's profit in a certain period. Meanwhile, the dividend policy will not be good if the source of the determination comes from debt or company capital. For future researchers, this study is expected to be used as an additional reference for further research on the effect of financial disclosure, ownership structure on firm value moderated by dividend policy.

\subsection{Suggestions and Limitations}

The limitation of this study is that in detecting firm value only uses financial disclosure, ownership structure and dividend policy, while in detecting firm value there are other variables such as capital structure. In the Indonesian context, indicators of liquidity ratio and managerial ownership do not apply to LQ45 companies in measuring financial disclosure and ownership structure. 
Suggestions for further research are suggested to add other variables in detecting firm value such as capital structure and use signal theory to add to the theoretical basis used. The next researcher is suggested to look for other indicators to measure financial disclosure and ownership structure on observations in the LQ45 company.

\section{References}

[1] Abdillah, W., dan Hartono, J. (2015). Partial Least Square (PLS): alternatif structural equation modeling (SEM) dalam penelitian bisnis. Yogyakarta: Penerbit Andi, 22, 103150.

[2] Agus, Sartono. (2011). Manajemen Keuangan Teori dan Aplikasi. Yogyakarta: BPFE.

[3] Al-Kuwari, D. (2009). Determinants of the dividend payout ratio of companies listed on emerging stock exchanges: The case of the Gulf Cooperation Council (GCC) countries. Global Economy \& Finance Journal. Vol. 2 No. 2. Hal. 38-63.

[4] Apriada, Kadek dan Sadha, Made.S. (2016). Pengaruh Struktur Kepemilikan Saham, Struktur Modal dan Profitabilitas pada Nilai Perusahaan”. E- Journal Ekonomi dan Bisnis Universitas Udayana. Vol 5. No.2 Hal. 2337- 3067.

[5] Eckbo, B.E., Verma, S., (1994). Managerial shareownership, voting power, and cash dividend policy. The Journal of Corporate Finance. Vol. 1 Hal. 33- 62.

[6] Fahdiansyah, Restu., Qudsi, Jihadil., \& Bachtiar, Adam. (2017). Struktur Kepemilikan dan Nilai Perusahaan: (Studi Pada Perusahaan Manufaktur Yang Listing di Bursa Efek Indonesia). Jurnal Varian. Vol. 1 No. 2.

[7] Faisal. (2005). Analisis Agency Costs, Struktur Kepemilikan dan Mekanisme Corporate Governance. Jurnal Riset Akuntansi Indonesia. Vol. 8 No. 2 Hal. 175-190.

[8] Gayatri, Ni Luh Putu Rassri dan I Ketut Mustanda. 2013. Pengaruh Struktur Modal, Kebijakan Dividen dan Keputusan Investasi Terhadap Nilai Perusahaan. Jurnal Manajemen dan Kewirausahaan.

[9] Ghozali, I., dan Latan, H. (2012). Partial Least Square: Konsep, Teknik dan Aplikasi Smart PLS 2.0 M3. Semarang: Badan Penerbit Universitas Diponegoro.

[10] Jensen, M., dan Jerold B. Warner. (1988), The Distribution of Power Among Corporate Managers, Shareholders, and Directors. Journal of Financial Economics. Vol. 20 No. 1 Hal 3-24.

[11] Jensen \& Meckling. (1976). The Theory of The Firm: Manajerial Behaviour, Agency Cost, and Ownership Structure. Journal of Financial and Economics. No. 3 Hal. 305360 .

[12] Kasmir. (2014). Analisis Laporan Keuangan. Edisi Satu. Cetakan Ketujuh. Jakarta: PT Raja Grafindo Persada.

[13] Klapper, L. \& Love. I. (2002). Corporate governance, investor protection, and performance in emerging markets. Washington, DC. United States: World Bank. Mimeographed document.

[14] Mmbone, J.M, Hood, A.A \& Wambui, J.M. (2015). The Relationship between Voluntary Disclosure and Financial Performance of Companies Quoted At the Nairobi Securities Exchange. International Journal od Managerial Studies and Research (LIMSR). Vol. 3 No. 6 Hal. 2349-0349.

[15] Noerirawan, Moch Ronni dan Abdul Muid. (2012). Pengaruh Faktor Internal Dan Eksternal Perusahaan Terhadap Nilai Perusahaan. Diponegoro Journal Of Accounting. Vol. 1 No. 2 Hal. 1-12. 
[16] Senata, Maggee. (2016). Pengaruh Kebijakan Dividen Terhadap Nilai Perusahaan Yang Tercatat Pada Indeks LQ-45 Bursa Efek Indonesia. Jurnal Wira Ekonomi Mikroskil .Vol. 6.No. 1.

[17] Short, H.; H. Zhang; dan K. Keasey. (2002). The Link between Dividend Policy and Institutional Ownership. Journal of Corporate Finance. Vol. 8 Hal. 105-122

[18] Worthington, A.C. and West Tracey. (2004). Australian evidence concerning the information content of economic value-added. Australian Journal of Management, Vol. 29, No. 2, pp. 201-24.

[19] Yuniati, Mei, Kharis Raharjo dan Abrar Oemar. (2016). Pengaruh Kebijakan Dividen, Kebijakan Hutang, Profitabilitas, dan Struktur Kepemilikan Terhadap Nilai Perusahaan Pada Perusahaan Manufaktur yang Terdaftar di Bursa Efek Indonesia Periode 20092014. Journal of Accounting. Vol. 2 No. 2. 